\title{
Radiation-Induced Effect on Spin-Selective Electron Transfer through Self-Assembled Monolayers of ds-DNA
}

\author{
Neeraj Bangruwa ${ }^{1}$, Manish Srivastava ${ }^{2}$ and Debabrata Mishra ${ }^{1, *}$ \\ 1 Department of Physics and Astrophysics, University of Delhi, New Delhi 110007, India; \\ nbangruwaphysics@gmail.com \\ 2 Department of Chemical Engineering and Technology, Indian Institute of Technology, (BHU), \\ Varanasi 221005, India; 84.srivastava@gmail.com \\ * Correspondence: dmishra@physics.du.ac.in
}

Citation: Bangruwa, N.; Srivastava, M.; Mishra, D. Radiation-Induced Effect on Spin-Selective Electron Transfer through Self-Assembled Monolayers of ds-DNA. Magnetochemistry 2021, 7, 98. https://doi.org/10.3390/ magnetochemistry7070098

Academic Editor: David S. Schmool

Received: 12 May 2021

Accepted: 5 July 2021

Published: 8 July 2021

Publisher's Note: MDPI stays neutral with regard to jurisdictional claims in published maps and institutional affiliations.

Copyright: (C) 2021 by the authors Licensee MDPI, Basel, Switzerland. This article is an open access article distributed under the terms and conditions of the Creative Commons Attribution (CC BY) license (https:/ / creativecommons.org/licenses/by/ $4.0 /)$.

\begin{abstract}
Stability of the DNA molecule is essential for the proper functioning and sustainability of all living organisms. In this study, we investigate the effect of gamma radiation ( $\gamma$-radiation) on spin-selective electron transfer through double strand (ds)DNA molecules. Self-assembled monolayers (SAMs) of 21-base long DNA are prepared on Au-coated Ni thin film. We measure the spin polarization (\%) of the SAMs of ds-DNA using the spin-dependent electrochemical technique. We use a Cs-based $\gamma$-radiation source to expose the SAMs of ds-DNA immobilized on thin films for various time intervals ranging from $0-30 \mathrm{~min}$. The susceptibility of DNA to $\gamma$-radiation is measured by spin-dependent electrochemistry. We observe that the efficiency of spin filtering by ds-DNA gradually decreases when exposure (to $\gamma$-radiation) time increases, and drops below $1 \%$ after $30 \mathrm{~min}$ of exposure. The change in spin polarization value is related either to the conformational perturbation in DNA or to structural damage in DNA molecules caused by ionizing radiation.
\end{abstract}

Keywords: DNA; radiation; CISS effect; magnetoelectrochemistry; spin; chiral

\section{Introduction}

DNA is a genetic material and is crucial to the smooth functioning of all living creatures. It is a vital biological polymer that carries genetic information and plays an important role in DNA-Protein (or DNA) interaction [1-4]. Radiation-induced damage to DNA may lead to the generation of mutagenic genotoxic lesions $[5,6]$. These radiation sources primarily include UV, $\mathrm{X}$-rays, and $\gamma$-rays, which either cause damage to DNA bases and/or single, double strand breaks [7-9]. Consequently, damaged DNA may affect the electron/spin transfer through ds-DNA. Note that several biological functions, including nucleic acid synthesis, repair, and oxidative stress drive (transfer) electrons through distances longer than the nanometer range [10,11]. In the special case of chiral molecules, it has been demonstrated, experimentally and theoretically, by the Ron Naaman group and others, that the spin-selective electron transfer occurs in a variety of biomolecules, and the phenomenon is popularly known as chiral-induced spin selectivity (CISS) effect which has many implications, including bio-recognition, enantioselection and spin-specific chemical reactions [12-15]. It has been found experimentally that ds-DNA acts as an excellent spin filter (up to $60 \%$ at room temperature) due to the CISS effect, owing to the presence of its helical (chiral) structure [12]. Moreover, spin selectivity through DNA is dependent on its secondary structure, such as length, pitch, helicity and sequence etc. [12,16,17]. Any perturbation in the secondary structure (helix) of DNA pertaining to these parameters would likely affect the spin selectivity of the ds-DNA under study. In a recent study, S. Mishra et al. have shown experimentally that the yield of spin-polarized electrons through oxidatively damaged DNA either increases or decreases depending on electrons' pathways (through the backbone or bases of DNA) [18]. This indicates that the damage site is crucial 
in determining the spin selectivity of damaged DNA. X. Pan et al. have shown experimentally that the phosphate backbone of DNA is the site of attack for the low-energy electron radiation causing damage to DNA [19]. It is also well known that ionizing radiation such as $\gamma$ - ray causes various lesions in DNA, including single, double strand breaks; oxidized bases; and abasic sites that may affect the spin-selective electron transfer through DNA in different ways for the aforementioned lesions [20]. Thus, it is imperative to determine the effect of ionizing radiation on spin-selective electron transfer through ds-DNA.

To study the effect of ionizing radiation on ds-DNA, we took a 21-base DNA sequence of the operator DNA (ORR3) that binds specifically to the protein AraR from Bacillus subtilis [21]. SAM of ds-DNA was prepared on $\mathrm{Ni} / \mathrm{Au}$ thin film and subsequently exposed to $\gamma$-radiation at different time scales. The spin-selective electron transfer through dsDNA and its evolution with exposure time was measured using the spin-dependent electrochemical technique. The measured spin polarization was then correlated with the structure of DNA using differential pulse voltammetry and FT-IR spectroscopy, post radiation exposure. We found that there was a steady decline in spin selectivity with radiation exposure, even when the DNA was not denatured completely.

\section{Results and Discussions}

Figure 1a shows a schematic diagram of the side view of $\mathrm{Ni} / \mathrm{Au}$ thin film on the $\mathrm{SiO}_{2} / \mathrm{Si}$ surface. The crystal structure of the surface of the $\mathrm{Ni} / \mathrm{Au}$ film was probed by X-ray diffraction (XRD), and the corresponding XRD pattern is shown in Figure 1b. The XRD technique is used to study the presence of different phases and crystalline properties of the sample under study.

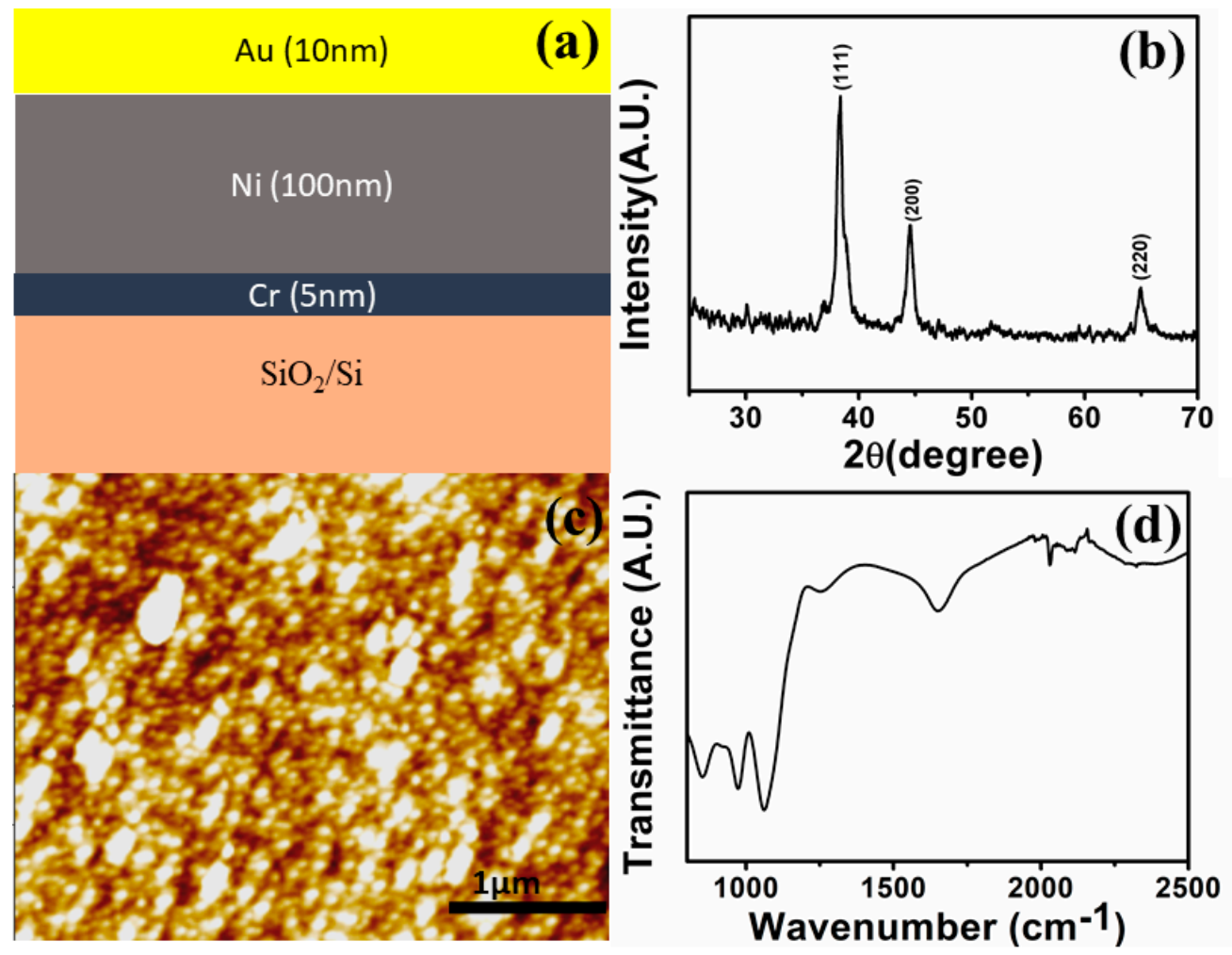

Figure 1. (a) Schematic diagram of $\mathrm{Ni} / \mathrm{Au}$ thin film (Side view) on the $\mathrm{SiO}_{2} / \mathrm{Si}$ substrate. (b) XRD pattern, (c) atomic force microscope (AFM) image of bare Ni/Au thin film, and (d) FTIR spectra of ds-DNA monolayer on $\mathrm{Ni} / \mathrm{Au}$ thin film.

Planes corresponding to $2 \theta$ angles around $38.1^{\circ}, 44.3^{\circ}$, and $64.5^{\circ}$ represent (111), (200), and (220) reflections from the Au overlayer [22]. The presence of sharp crystalline peaks demonstrates the polycrystalline behavior of the Au overlayer. The AFM image, as 
shown in Figure 1c, shows the topography of the Au surface where the grains of Au are distributed uniformly over the Ni surface. After the preparation of the $\mathrm{Ni} / \mathrm{Au}$ electrodes, SAMs of ds-DNA were immobilized on the as-prepared $\mathrm{Ni} / \mathrm{Au}$ films following the method described earlier $[12,23]$. Formation of the SAMs of ds-DNA was characterized by FT-IR spectroscopy and is shown in Figure 1d. The characteristic peaks of ds-DNA in the range of $891 \mathrm{~cm}^{-1}-1215 \mathrm{~cm}^{-1}$ correspond to the asymmetric and symmetric $P O_{4}^{-}$groups of the phosphodiester deoxyribose backbone [24]. The peak observed at $1650 \mathrm{~cm}^{-1}$ corresponds to guanine bases [25]. These results confirm the immobilization of ds-DNA onto Au-coated $\mathrm{Ni}$ thin film.

Spin-dependent electron transfer through ds-DNA has been recorded by cyclic voltammetry $(\mathrm{CV})$ in the presence of a magnetic field by using a permanent magnet of field strength $0.5 \mathrm{~T}$. The I-V measurements were performed with a two-electrode system, and platinum wire was taken as a shared reference/counter electrode [26]. Note that the two-electrode system can be used for the measurement of small current with a larger surface area of the counter electrode. We have also checked the stability of current with multiple CV measurements and found that there was no fluctuation of current and/or drift of voltage with time (data not shown here). The SAMs of ds-DNA on the Ni/Au surface and $\mathrm{Pt}$ wire were taken as the working and counter electrodes, respectively. CV measurements were taken in an aqueous solution of potassium phosphate buffer saline (PBS) containing $2 \mathrm{mM} \mathrm{K}_{4}\left[\mathrm{Fe}(\mathrm{CN})_{6}\right] .3 \mathrm{H}_{2} \mathrm{O}$ and $2 \mathrm{mM} \mathrm{K}_{3}\left[\mathrm{Fe}(\mathrm{CN})_{6}\right]$ and $50 \mathrm{mM} \mathrm{KCl}$ at $\mathrm{pH}=7.2$. Note that non-intercalated redox probes, such as hexacyanoferrate and ferrocene, have been used previously by S. Mishra et al. to study the spin polarizing behavior of a DNA molecule in a Hall device setup [16,18]. As per the established protocol, bias voltage with a fixed scan rate of $50 \mathrm{mV} / \mathrm{s}$ was applied in the range of $-0.40 \mathrm{~V}$ to $+0.45 \mathrm{~V}$ across the electrodes. In the forward scan of the current, at a particular voltage of $0.09 \mathrm{~V}$, an oxidation peak appears due to the oxidation of $\mathrm{Fe}^{2+}$ species present in the solution. In this process, $\mathrm{Fe}^{2+}$ loses an electron, which subsequently passes through the interface of the SAMs of DNA to the working electrode. When the direction of the I-V scan is reversed, a similar peak at around $-0.03 \mathrm{~V}$ appears due to the reduction of $\mathrm{Fe}^{3+}$ to $\mathrm{Fe}^{2+}$. The redox reaction in the solution phase can be represented by [27]:

$$
\mathrm{Fe}^{3+}+e^{-} \rightleftharpoons \mathrm{Fe}^{2+}
$$

To detect the CISS effect, spin injection through the SAMs of ds-DNA, while sweeping the DC bias voltage, was carried out using a permanent magnet (strength $=0.5 \mathrm{~T}$ ) placed underneath the $\mathrm{Ni} / \mathrm{Au}$ thin film. The difference in the peak current provides an estimate of spin polarization following the equation $[13,14]$

$$
P_{s}=\frac{I \uparrow-I \downarrow}{I \uparrow+I \downarrow} \times 100
$$

Figure 2 represents the schematic diagram of the device and the sequence of measurements for the samples under study. Each circular patch of Au with a diameter of $2 \mathrm{~mm}$ on a continuous $\mathrm{Ni}$ thin film constitutes a device, along with $\mathrm{Pt}$ wire as a reference/counter electrode. Figure 2a shows the cyclic voltammogram of the SAMs of ds-DNA on Ni/Au thin film for two different directions (up or down) of the magnetic field using a permanent magnet. Here DC potential was gradually varied from $-0.40 \mathrm{~V}$ to $+0.45 \mathrm{~V}$, and the corresponding current was measured. We found that the nature of the $\mathrm{CV}$ curve was sharp and reversible and estimated the spin polarization value, $\left|P_{S}\right|$, to be $3.5 \%$ for the as-prepared ds-DNA coated Ni/Au film. Subsequently, the sample was exposed to the $\gamma$ - radiation of the $\mathrm{Cs}^{137}$ source with a constant dose $(690 \pm 20 \mu \mathrm{rem} / \mathrm{h})$ for different time intervals of $0 \mathrm{~min}, 2 \mathrm{~min}, 10 \mathrm{~min}, 20$, and $30 \mathrm{~min}$, respectively. The flux of the radiation was kept fixed for all the samples. Note that a freshly prepared sample was taken each time for radiation exposure with the similar setup, and the spin polarization was calculated following the procedure described above. 


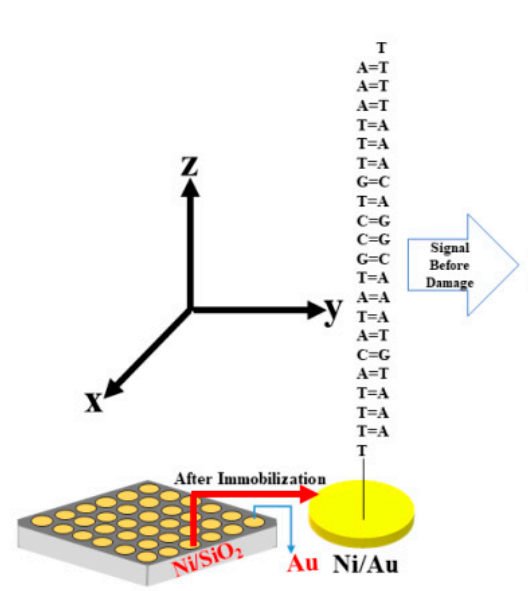

(a)

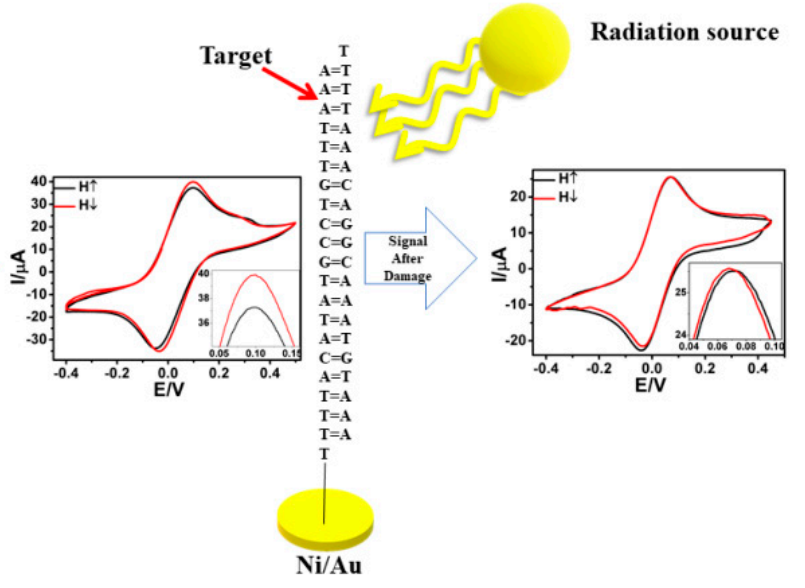

(b)

Figure 2. Schematic representation of the working electrode/device: results of the electrochemical measurements of the SAMs of ds-DNA on the Ni/Au (a) before and (b) after the radiation-induced effect in DNA. The electrode is made up of an array of devices consisting of circular patches of $\mathrm{Au}$ with a diameter of $2 \mathrm{~mm}$ on a continuous $\mathrm{Ni}$ thin film. Z-direction represents the spin quantization axis and is normal on the surface of the thin film.

Figure 3a-e represents the CV curves recorded after an exposure time of $t=0,2,10$, 20, $30 \mathrm{~min}$. Figure $3 \mathrm{f}$ represents the $\mathrm{CV}$ curve of a bare Ni/Au thin film as the control experiment.
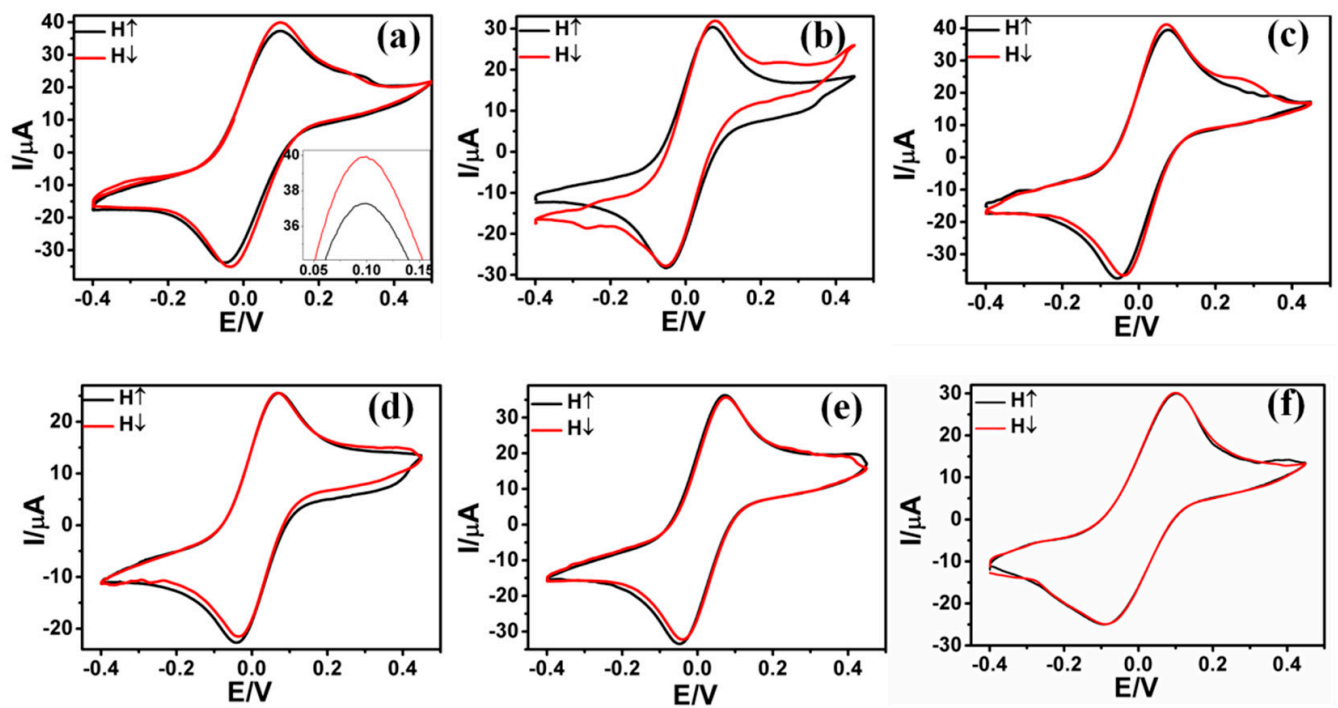

Figure 3. I-V curves of the SAMs of ds-DNA on Ni/Au thin film (batch-1, series-I) with $2 \mathrm{mM} \mathrm{K}_{4}$ [Fe $\left.(\mathrm{CN})_{6}\right] .3 \mathrm{H}_{2} \mathrm{O} / \mathrm{K}_{3}\left[\mathrm{Fe}(\mathrm{CN})_{6}\right]$ redox couple at $\mathrm{pH}=7.2$, potassium phosphate buffer and $50 \mathrm{mM}$ $\mathrm{KCl}$ base electrolyte, aqueous solution: initial potential $=-0.4 \mathrm{~V}$; final potential $=+0.45 \mathrm{~V}$; scan rate $=50 \mathrm{mV} / \mathrm{s}$ for exposure time $t=(\mathbf{a}) 0 \mathrm{~min}$ (b) $2 \mathrm{~min}$ (c) $10 \mathrm{~min}$ (d) $20 \mathrm{~min}$ and (e) $30 \mathrm{~min}$. (f) I-V curves of a bare $\mathrm{Ni} / \mathrm{Au}$ thin film from the control experiment. The applied magnetic field in two different directions of the magnetic field $(\mathrm{H}=0.5 \mathrm{~T})$ was kept constant for all the samples measured in the present study.

The peak currents for the two different directions of the applied magnetic fields overlap for both the oxidation and reduction processes for bare $\mathrm{Ni} / \mathrm{Au}$ showing no spin filtering on the part of bare $\mathrm{Ni} / \mathrm{Au}$, as expected. But for the SAM-coated $\mathrm{Ni} / \mathrm{Au}$ sample, we observed a difference in the current values in two directions (up and down) of the magnetic field for both oxidation and reduction processes. When the sample was exposed 
to $\gamma$ - radiation, we observed that the difference in the oxidation peak currents for the two directions of the magnetic field decreased gradually, and the symmetric I-V curve (in the forward and reverse scans, Figure 3a) was transformed into a non-symmetric one for samples treated with different radiation doses (Figure 3b,c). Similar non-symmetric behavior in I-V curves has been reported by P.C. Mondal et al. for a chiral-polymer-coated Ni sample [28]. These authors have attributed the presence of a barrier in the conduction of electrons from the surface of $\mathrm{Ni}$ to the solution to the observed non-symmetric behavior of I-V curves. However, another study by P.C. Mondal et al. [29] shows a similar nonsymmetric I-V curve in L-Cys-TBO-coated $\mathrm{Ni} / \mathrm{Au}$ thin film. Surface-specific reactions could be one of the reasons for the observed behavior and require thorough investigation, which is beyond the scope of the present study. Note that the oscillatory current recorded for the sample in Figure $3 \mathrm{~b}$ after the oxidation and reduction potential $(> \pm 0.2 \mathrm{~V})$ may be attributed to the unstable interface specific to that particular sample at a higher bias voltage. Nevertheless, the absolute spin polarization value, $\left|P_{S}\right|$, was calculated using Equation (2). Figure 4 represents the $\left|P_{S}\right|$ vs. time (dose) curves for two series of samples for different exposure periods.

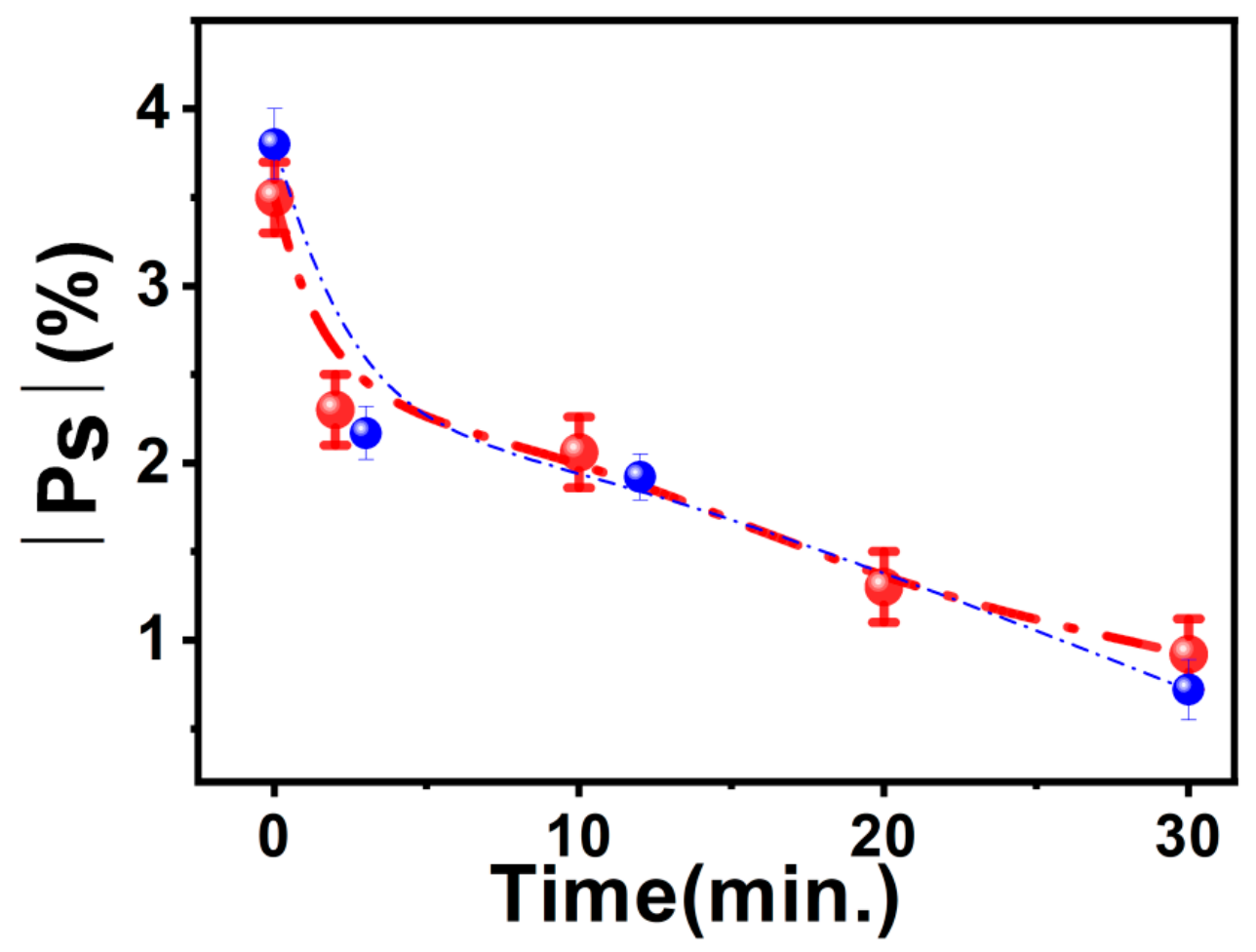

Figure 4. Absolute spin polarization value, $\left(\left|P_{S}\right|\right)$ vs. exposure time curves for the SAMs of ds-DNA, as calculated by the I-V curves from series-I (large sphere) and series-II (small sphere) samples. (The dash-dotted line is the B-spline interpolation of the measured data points and is a guide to the eye only.) The radiation dose (in $\mathrm{min}$ ) for series-I is $0 \mathrm{~min}, 2 \mathrm{~min}, 10 \mathrm{~min}, 20 \mathrm{~min}$ and $30 \mathrm{~min}$ and for series-II is $0 \mathrm{~min}, 3 \mathrm{~min}, 12 \mathrm{~min}$ and $30 \mathrm{~min}$.

When the SAMs of DNA-coated working electrodes were exposed to radiation for $2 \mathrm{~min}$, the absolute spin polarization value was decreased to $2.3 \%$. A similar trend in $\left|\mathrm{P}_{\mathrm{S}}\right|$ value was observed for the extended time durations, and $\left|\mathrm{P}_{\mathrm{S}}\right|$ value decreased to $1.3 \%$ after $20 \mathrm{~min}$ of radiation exposure. However, after $30 \mathrm{~min}$, spin polarization value was reduced considerably and was found to be $0.8 \%$. In order to confirm the reproducibility of the pattern ( $\left|\mathrm{P}_{\mathrm{S}}\right|$ vs. exposure time), another series of samples (series II) was exposed to radiation at a slightly different interval of exposure time $(t=0,3,12,30 \mathrm{~min})$, and the calculated $\left|\mathrm{P}_{\mathrm{S}}\right|$ value was plotted as a function of exposure time, along with series-I samples for comparison (See Figure 4). Note that the error bars were determined from 
the multiple measurements of six batches of samples ( 3 Nos. for each series) consisting of 30 devices. The error bars in the figure represent the standard error of mean with $p \sim 0.5$. From the results of series-I and -II samples, it is obvious that the effect of $\gamma$-radiation on the spin filtering properties of ds-DNA follows the same trend for both series of samples. These results confirm that the spin filtering ability of ds-DNA diminishes after radiation exposure, and $\left|P_{S}\right|$ becomes less than $1 \%$ after $30 \mathrm{~min}$ of exposure to $\gamma$-radiation. To rationalize the radiation-induced effect on spin polarization, we tried to determine the correlation between the structure and observed $\left|\mathrm{P}_{\mathrm{S}}\right|$ value for ds-DNA using both electrochemical and optical methods. In the electrochemical method, differential pulse voltammetry (DPV) was performed on samples with different doses, and the results are presented in Figure 5.
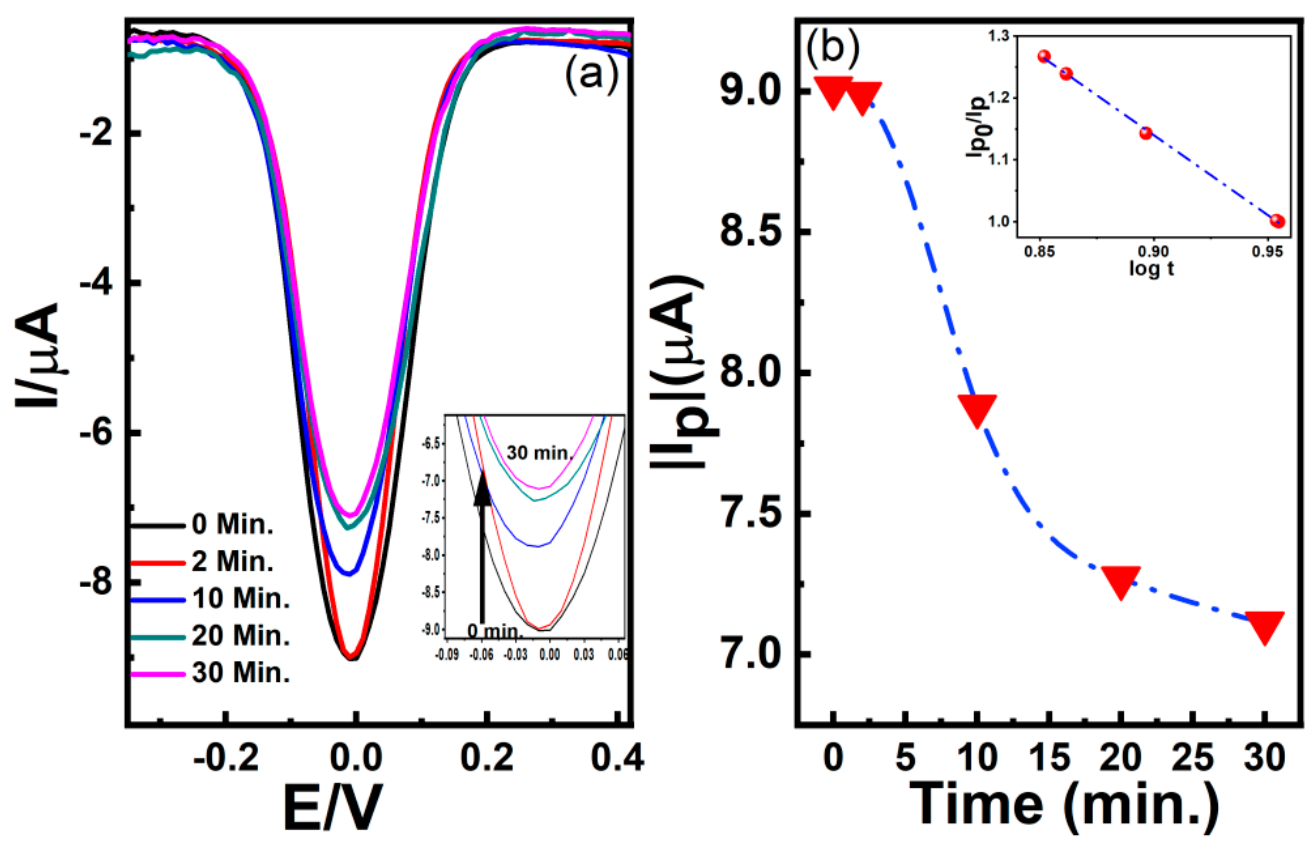

Figure 5. (a) Differential pulse voltammogram (in the reverse scan) of the SAMs of ds-DNA on $\mathrm{Ni} / \mathrm{Au}$ after $t=0 \mathrm{~min}, 2 \mathrm{~min}, 10 \mathrm{~min}, 20 \mathrm{~min}$ and $30 \mathrm{~min}$ of $\gamma$-radiation, (b) the absolute peak current " $\left|\mathrm{I}_{\mathrm{P}}\right|$ " extracted from (a) is plotted as a function of time. (The experiment was performed with $50 \mathrm{mM} \mathrm{KCl}$ and $2 \mathrm{mM} \mathrm{K} 4[\mathrm{Fe}(\mathrm{CN}) 6] / \mathrm{K} 3[\mathrm{Fe}(\mathrm{CN}) 6]$ in a phosphate buffer solution at $\mathrm{pH}=7.2$. The volume of the electrolytes taken was $2 \mu \mathrm{L}$. (The dash-dotted line is a B-spline interpolation of the measured data points and is a guide to the eye only). The inset in (b) shows the linear fit of $\mathrm{I}_{\mathrm{P} 0} / \mathrm{I}_{\mathrm{P}}$ vs. $\log (\mathrm{t})$. $\mathrm{I}_{\mathrm{P} 0}$ (absolute value) represents the peak current at $t=0 \mathrm{~min}$, and $\mathrm{I}_{\mathrm{P}}$ represents the peak current of samples with a different time span of radiation exposure. Note that the sample area and the volume of electrolyte were kept fixed for all the samples.

In this technique, an AC pulse of finite width is superimposed on the DC bias, either in the forward scan or in the reverse scan. The pulse amplitude was kept fixed at $10 \mathrm{mV}$. The pulse width and pulse period were taken to be $0.01 \mathrm{~s}$ and $0.5 \mathrm{~s}$, respectively. Figure $5 \mathrm{a}$ shows the DPV curves for SAMs of ds-DNA treated with different doses of $\gamma$-radiation. As the radiation exposure duration increases, the peak current of the DPV curves drops gradually due to the impeded charge transfer in DNA, indicating structural changes. In Figure $5 b$, the peak current, $\left|I_{P}\right|$, measured by DPV is plotted against the time of exposure to $\gamma$-radiation, which shows a decreasing trend in the absolute current value. Note that a similar trend has also been observed by Liu et al. for UV-induced DNA damage using DPV methods [30]. Note that the DPV technique is an established tool to detect DNA damage in many different processes [31,32]. The inset in Figure $5 \boldsymbol{b}$ shows a perfect linear fit between $\mathrm{I}_{\mathrm{P} 0} / \mathrm{I}_{\mathrm{P}}$ and $\log t$, whereas $\mathrm{I}_{\mathrm{P} 0}$ represents the current value (absolute) before the $\gamma$-irradiation. In order to further verify the structural changes in DNA due to radiation, FT-IR spectra were recorded for all samples each time they were exposed to radiation (see 
Figure 6). The peaks found in the range of $891-1215 \mathrm{~cm}^{-1}$ correspond to asymmetric and symmetric $\mathrm{PO}_{4}^{-}$groups of the phosphodiester deoxyribose backbone. In general, the peaks obtained in the range of $1515-1650 \mathrm{~cm}^{-1}$ match with $\mathrm{C}=\mathrm{O}, \mathrm{C}=\mathrm{N}, \mathrm{C}=\mathrm{C}$ stretching and exocyclic $-\mathrm{NH}_{2}$ bending vibrations in the DNA bases [24,25]. We notice a broad peak centered around $1650 \mathrm{~cm}^{-1}$, which corresponds to the guanine bases of DNA. The guanine peak for $t=2$ min exposure time of DNA (Figure $6 \mathrm{~b}$ ) has been found to be less intense than the other spectra. The apparent discrepancy in peak intensity might be due to the different orientation or adsorption of molecules on the surface of the $\mathrm{Ni} / \mathrm{Au}$ thin film compared with the rest of the samples. However, the peak position in the FT-IR spectra does not change more significantly than that of the unexposed one. When the exposure time of the $\gamma$-radiation was increased to $20 \mathrm{~min}$, we observed a decrease in the relative intensity of peaks compared with that of unexposed ones.

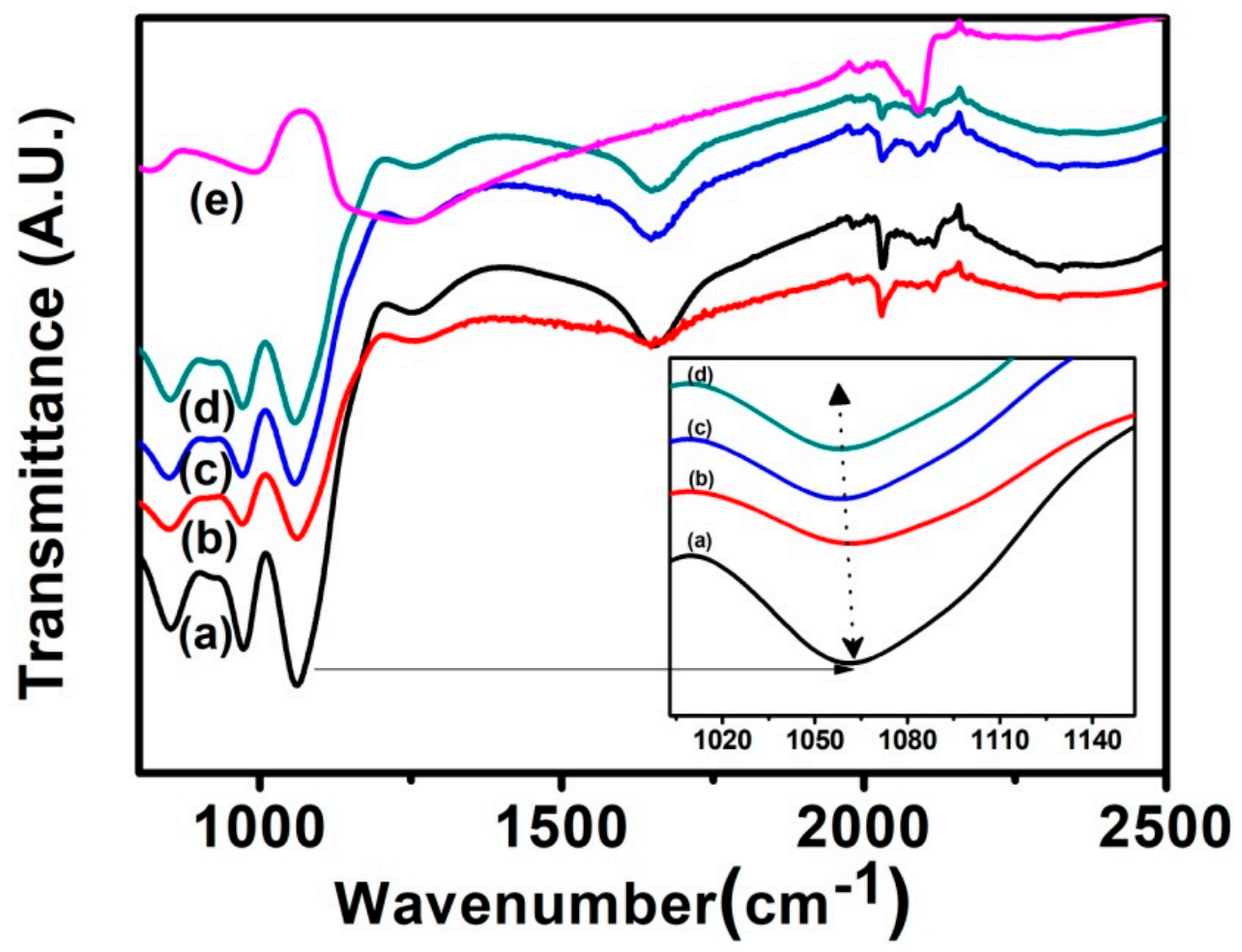

Figure 6. FTIR spectra of the SAMs of ds-DNA for exposure time $t=$ (a) $0 \mathrm{~min}$ (b) $2 \mathrm{~min}$ (c) $10 \mathrm{~min}$ (d) $20 \mathrm{~min}$ and (e) $30 \mathrm{~min}$. Inset shows the magnified view of the peak positions of spectra at around $1060 \mathrm{~cm}^{-1}$.

After carefully examining Figure 6, it is clear that all the characteristic peaks are preserved until the exposure time $t=20 \mathrm{~min}$. However, we see a gradual decrease in the $\left|P_{S}\right|$ value with an increase in the exposure time. It can be inferred that due to the formation of local stress/conformational change in the DNA strand or strand break after the irradiation, the strand is possibly in a metastable state while preserving its basic structure [33-35]. Note that there is a minor shift in the peak position at $1060 \mathrm{~cm}^{-1}$, which represents the deoxyribose C-O stretching of DNA molecules (see inset of Figure 6) [36]. Initially the peak position (extremum) for the 2 min radiation-treated sample shifts to a higher wave number than the unexposed one, followed by a shift in peak position to lower wave number for the rest of the different dose-treated samples (until $20 \mathrm{~min}$ ). A similar trend in peak shift has also been found in previously published research on the organic monolayer on Si's surface [37]. This shift in the peak position indicates that there is a change in the mode of vibrations due to the change in structure (local stress) because of the formation of intermediate complexes after irradiation. Any change in the structure/damage in DNA is reflected in the change in peak positions or intensity in FT-IR 
spectra and has been verified experimentally as reported in the literature previously [38-42]. Very recently, it has been demonstrated theoretically that vibration enhances the electronic coherent effect, and spin-dependent electron-phonon coupling brings more tunneling paths in the ds-DNA molecules promoting CISS-induced polarization [43-47]. The change in the vibration mode could be one of the reasons for the reduction in the spin-polarized electrons transported through DNA. For $t=30 \mathrm{~min}$, we found that the characteristic peaks at $1060 \mathrm{~cm}^{-1}$, including the Guanine peaks at $1650 \mathrm{~cm}^{-1}$, are absent, and complexes are formed showing the complete denaturation of ds-DNA. This is also accompanied by a meagre $\left|\mathrm{P}_{\mathrm{S}}\right|$ value for the exposure time of $t=30 \mathrm{~min}$. The possibility of strand break or distortion in the secondary structure caused by the $\gamma$-ray is also inevitable and may inhibit coherent spin transport through the DNA molecule. Molecular dynamics simulations or in situ monitoring of structural changes during radiation exposure on the DNA sample would further broaden understanding of the correlation between spin transfer and structural conformation. Nevertheless, our results suggest that there is one-to-one correlation between radiation exposure time and the yield of spin polarization through ds-DNA.

\section{Materials and Methods}

\subsection{Materials}

21-base-long DNA primer and its reverse primer were procured from Sigma-Aldrich. All the essential chemicals, including Potassium hexacyanoferrate (III) $\left[\mathrm{K}_{3} \mathrm{Fe}(\mathrm{CN})_{6}\right]$, Potassium Hexacyanoferrate (II) trihydrate $\left[\mathrm{K}_{4} \mathrm{Fe}(\mathrm{CN})_{6} \cdot 3 \mathrm{H}_{2} \mathrm{O}\right]$, Potassium Chloride $(\mathrm{KCl})$, Potassium phosphate monobasic $\left(\mathrm{KH}_{2} \mathrm{PO}_{4}\right)$, and potassium phosphate dibasic $\left(\mathrm{K}_{2} \mathrm{HPO}_{4}\right)$, were purchased from Sigma-Aldrich. Molecular grade water was purchased from G Biosciences. Granules of $\mathrm{Cr}, \mathrm{Ni}$, and $\mathrm{Au}$ (purity $\geq 99.99 \%$ ), and Silicon wafers N-type $<100>$ $(0.001-0.009 \Omega-\mathrm{cm})$ of $480 \pm 15 \mu \mathrm{m}$, were purchased from S.K. Novel materials \& Technologies. A Cs ${ }^{137}$-based radiation source was acquired from the departmental nuclear physics teaching laboratory (M.Sc.).

\subsection{Preparation of Thin Film and Monolayers}

Under a high vacuum of $10^{-7}$ Torr, $\mathrm{Ni}$ thin film with a thickness of $100 \mathrm{~nm}$ was deposited on thermally grown silicon dioxide $\left(\mathrm{SiO}_{2}\right)$ using an electron beam evaporation technique. Then, $5 \mathrm{~nm}$ of chromium was used as an adhesion layer between $\mathrm{Ni}$ and $\mathrm{SiO}_{2}$. A shadow mask was used to make a patterned structure, $2 \mathrm{~mm}$ in diameter, of circular patches on the Ni thin film without breaking the vacuum. The thickness of Au was kept at $10 \mathrm{~nm}$. The thin film was immobilized by DNA molecules to form the self-assembled monolayers (SAMs) of ds-DNA described elsewhere. The sequence of the DNA is as follows (see Figure 2 for the double-strand formation).

\section{5'-AAATTTGTCCGTATACATTTT-(ThiC3)-3'-Primer}

\section{3'-TTTTAAACAGGCATATGTAAA-Reverse Primer}

For the preparation of SAMs, freshly prepared $\mathrm{Ni} / \mathrm{Au}$ thin film was cleaned in boiled acetone and ethanol for $15 \mathrm{~min}$ each and then dried with nitrogen gas and was exposed to UV light for removal of any organic contaminants present on the surface. It was then quickly washed with ethanol and dried with nitrogen gas again. The above thiol-modified DNA of $10 \mu \mathrm{M}$ concentration and its complementary strand were hybridized to make ds-DNA, as per the protocol described earlier [22]. Ni/Au thin film was gently covered with the solution of $10 \mu \mathrm{M}$ DNA and was left for $24 \mathrm{~h}$. The SAM-coated thin film was cleaned with $0.1 \mathrm{M}$ PBS of pH 7.2 and then dried using nitrogen gas.

\subsection{Electrochemical Measurements}

Electrochemical measurements were carried out with CORRTEST 350 potentiostat using a two-electrode system. Two series of devices were prepared (I and II) under similar conditions at different time intervals. A schematic diagram of the working electrode is shown in Figure 2. A permanent magnet (Nd-Fe-B) of field strength $0.5 \mathrm{~T}$ was placed beneath the thin-film device with the help of a holder for switching the direction of the 
magnetic field without disturbing the sample. Other details of the measurement are mentioned in the results and discussion section.

\subsection{Exposure to Radiation}

For exposure to $\gamma$-radiation, a $\mathrm{Cs}^{137}$ source was used in the study. The sample was kept with a suitable holder at a distance of $3 \mathrm{~cm}$ in air from the outlet of the radiation source. Fresh samples were taken for different time scales of exposure to radiation. Care was taken to maintain the time period of exposure.

FT-IR spectra were recorded by a NICOLET iS50 FT-IR Spectrophotometer in ATR mode with slow scan speed. An XRD pattern was obtained from the Rigaku Ultima IV $X$-ray diffractometer with a $\mathrm{Cu} K \alpha$ source $\left(\lambda=1.54 \mathrm{~A}^{\circ}\right)$ using a scan rate of $1^{0}$ per min.

\section{Conclusions}

We examined the effect of $\gamma$-radiation on spin-selective electron transfer through a short ds-DNA strand. Self-assembled monolayers of DNA on Ni/Au thin films were exposed to $\gamma$-radiation for different periods $(0-30 \mathrm{~min})$. The spin selectivity was then probed by spin-dependent electrochemistry. We found that there was a gradual decrease in the $\left|P_{S}\right|$ value from $3.5 \%$ for $t=0 \mathrm{~min}$ to $0.8 \%$ for $t=30 \mathrm{~min}$, and $\left|P_{\mathrm{S}}\right|$ dropped below 1\% when the DNA was damaged completely. The results from the DPV and FT-IR measurements reveal that there was conformational perturbation or damage to the structure of DNA after prolonged exposure to radiation. A simultaneous decrease in the $\left|P_{S}\right|$ value with exposure time suggests that there is a correlation between the structure of DNA and the yield of spin-polarized electrons within it. Furthermore, our study paves the way for designing spin-dependent electrochemical devices to detect ionizing radiation-induced DNA damage.

Author Contributions: Conceptualization, D.M.; Data Curation, N.B.; Analysis, D.M., N.B., M.S.; Manuscript writing, D.M., M.S., N.B. All authors have read and agreed to the published version of the manuscript.

Funding: D.M. acknowledges the financial support from UGC through Grant No. F.4-5 (202FRP)/2015 (BSR), from MHRD-DST through grant No. IMP/2018/001668, SERB through grant number CRG/2018/004264 and IoE, University of Delhi through grant No. 1OE/FRP/PCMS/2020/27. MS acknowledges the Science and Engineering Research Board for SERB Research Scientist award [SB/SRS/2018-19/48/PS] and also to DST for DST INSPIRE Faculty award [IFA-13-MS-02].

Institutional Review Board Statement: Not Applicable.

Informed Consent Statement: Not Applicable.

Data Availability Statement: The data that support the findings of this study are available from the corresponding author upon reasonable request.

Acknowledgments: D.M. is grateful to Deepti Jain for providing DNA molecules. N.B. is thankful to UGC-New Delhi for providing the financial support.

Conflicts of Interest: Authors of the manuscript declare there is no conflict of interest.

\section{References}

1. Strey, H.H.; Podgornik, R.; Rau, D.C.; Parsegian, V.A. DNA-DNA interactions. Curr. Opin. Struct. Biol. 1998, 8, 309-313. [CrossRef]

2. Qiu, X.; Rau, D.C.; Parsegian, V.A.; Fang, L.T.; Knobler, C.M.; Gelbart, W.M. Salt-Dependent DNA-DNA Spacings in Intact Bacteriophage $\lambda$ Reflect Relative Importance of DNA Self-Repulsion and Bending Energies. Phys. Rev. Lett. 2011, 106, 028102. [CrossRef]

3. Maffeo, C.; Schöpflin, R.; Brutzer, H.; Stehr, R.; Aksimentiev, A.; Wedemann, G.; Seidel, R. DNA-DNA Interactions in Tight Supercoils Are Described by a Small Effective Charge Density. Phys. Rev. Lett. 2010, 105, 158101. [CrossRef] [PubMed]

4. Stingele, J.; Bellelli, R.; Boulton, S.J. Mechanisms of DNA-protein crosslink repair. Nat. Rev. Mol. Cell Biol. 2017, 18, 563-573. [CrossRef] [PubMed] 
5. Graupner, A.; Eide, D.M.; Instanes, C.; Andersen, J.M.; Brede, D.A.; Dertinger, S.D.; Lind, O.C.; Brandt-Kjelsen, A.; Bjerke, H.; Salbu, B.; et al. Gamma radiation at a human relevant low dose rate is genotoxic in mice. Sci. Rep. 2016, 6, 32977. [CrossRef] [PubMed]

6. Ward, J.F. Radiation Mutagenesis: The Initial DNA Lesions Responsible. Radiat. Res. 1995, 142, 362. [CrossRef]

7. Rastogi, R.P.; Richa; Kumar, A.; Tyagi, M.B.; Sinha, R.P. Molecular Mechanisms of Ultraviolet Radiation-Induced DNA Damage and Repair. J. Nucleic Acids 2010, 2010, 1-32. [CrossRef]

8. Brand, M.; Sommer, M.; Achenbach, S.; Anders, K.; Lell, M.; Löbrich, M.; Uder, M.; Kuefner, M.A. X-ray induced DNA doublestrand breaks in coronary CT angiography: Comparison of sequential, low-pitch helical and high-pitch helical data acquisition. Eur. J. Radiol. 2012, 81, e357-e362. [CrossRef]

9. Mavragani, I.V.; Nikitaki, Z.; Souli, M.P.; Aziz, A.; Nowsheen, S.; Aziz, K.; Rogakou, E.; Georgakilas, A.G. Complex DNA Damage: A Route to Radiation-Induced Genomic Instability and Carcinogenesis. Cancers 2017, 9, 91. [CrossRef]

10. Beratan, D.N. Why Are DNA and Protein Electron Transfer so Different? Annu. Rev. Phys. Chem. 2019, 70, 71-97. [CrossRef]

11. Kubař, T.; Elstner, M. What Governs the Charge Transfer in DNA? The Role of DNA Conformation and Environment. J. Phys. Chem. B 2008, 112, 8788-8798. [CrossRef]

12. Gohler, B.; Hamelbeck, V.; Markus, T.Z.; Kettner, M.; Hanne, G.F.; Vager, Z.; Naaman, R.; Zacharias, H. Spin Selectivity in Electron Transmission through Self-Assembled Monolayers of Double-Stranded DNA. Science 2011, 331, 894-897. [CrossRef] [PubMed]

13. Mishra, D.; Markus, T.Z.; Naaman, R.; Kettner, M.; Göhler, B.; Zacharias, H.; Friedman, N.; Sheves, M.; Fontanesi, C. Spindependent electron transmission through bacteriorhodopsin embedded in purple membrane. Proc. Natl. Acad. Sci. USA 2013, 110, 14872-14876. [CrossRef] [PubMed]

14. Kettner, M.; Göhler, B.; Zacharias, H.; Mishra, D.; Kiran, V.; Naaman, R.; Fontanesi, C.; Waldeck, D.H.; Sęk, S.; Pawłowski, J.; et al. Spin Filtering in Electron Transport through Chiral Oligopeptides. J. Phys. Chem. C 2015, 119, 14542-14547. [CrossRef]

15. Naaman, R.; Paltiel, Y.; Waldeck, D.H. Chiral molecules and the electron spin. Nat. Rev. Chem. 2019, 3, 250-260. [CrossRef]

16. Mishra, S.; Mondal, A.K.; Pal, S.; Das, T.K.; Smolinsky, E.Z.B.; Siligardi, G.; Naaman, R. Length-Dependent Electron Spin Polarization in Oligopeptides and DNA. J. Phys. Chem. C 2020, 124, 10776-10782. [CrossRef]

17. Zwang, T.; Hürlimann, S.; Hill, M.G.; Barton, J.-L.K. Helix-Dependent Spin Filtering through the DNA Duplex. J. Am. Chem. Soc. 2016, 138, 15551-15554. [CrossRef] [PubMed]

18. Mishra, S.; Poonia, V.S.; Fontanesi, C.; Naaman, R.; Fleming, A.M.; Burrows, C.J. Effect of Oxidative Damage on Charge and Spin Transport in DNA. J. Am. Chem. Soc. 2019, 141, 123-126. [CrossRef]

19. Pan, X.; Sanche, L. Mechanism and Site of Attack for Direct Damage to DNA by Low-Energy Electrons. Phys. Rev. Lett. 2005, 94, 198104. [CrossRef]

20. Chen, C.Z.; Sutherland, J.C. Gel electrophoresis method for quantitation of gamma ray induced single-and double-strand breaks in DNA irradiated in vitro. Electrophoresis 1989, 10, 318-326. [CrossRef]

21. Jain, D.; Narayanan, N.; Nair, D. Plasticity in Repressor-DNA Interactions Neutralizes Loss of Symmetry in Bipartite Operators. J. Biol. Chem. 2016, 291, 1235-1242. [CrossRef] [PubMed]

22. Dutta, I.; Munns, C.; Dutta, G. An X-ray diffraction (XRD) study of vapor deposited gold thin films on aluminum nitride (A1N) substrates. Thin Solid Films 1997, 304, 229-238. [CrossRef]

23. Rosenberg, R.A.; Mishra, D.; Naaman, R. Chiral Selective Chemistry Induced by Natural Selection of Spin-Polarized Electrons. Angew. Chem. Int. Ed. 2015, 54, 7295-7298. [CrossRef]

24. Patel, M.K.; Solanki, P.R.; Kumar, A.; Khare, S.; Gupta, S.; Malhotra, B.D. Electrochemical DNA sensor for Neisseria meningitidis detection. Biosens. Bioelectron. 2010, 25, 2586-2591. [CrossRef] [PubMed]

25. Patel, M.K.; Solanki, P.R.; Khandelwal, S.; Agrawal, V.V.; Ansari, S.A.; Malhotra, B.D. Self-assembled monolayer based electrochemical nucleic acid sensor forVibrio choleratedetection. J. Phys. Conf. Ser. 2012, 358, 012009. [CrossRef]

26. Faure, M.; Pallandre, A.; Chebil, S.; Le Potier, I.; Taverna, M.; Tribollet, B.; Deslouis, C.; Haghiri-Gosnet, A.-M.; Gamby, J. Improved electrochemical detection of a transthyretin synthetic peptide in the nanomolar range with a two-electrode system integrated in a glass/PDMS microchip. Lab Chip 2014, 14, 2800-2805. [CrossRef]

27. Elgrishi, N.; Rountree, K.; McCarthy, B.D.; Rountree, E.S.; Eisenhart, T.T.; Dempsey, J.L. A Practical Beginner's Guide to Cyclic Voltammetry. J. Chem. Educ. 2018, 95, 197-206. [CrossRef]

28. Mondal, P.C.; Kantor-Uriel, N.; Mathew, S.P.; Tassinari, F.; Fontanesi, C.; Naaman, R. Chiral conductive polymers as spin filters. Adv. Mater. 2015, 27, 1924-1927. [CrossRef]

29. Mondal, P.C.; Fontanesi, C.; Waldeck, D.H.; Naaman, R. Field and Chirality Effects on Electrochemical Charge Transfer Rates: Spin Dependent Electrochemistry. ACS Nano 2015, 9, 3377-3384. [CrossRef]

30. Liu, M.; Xu, J.; Yang, F.; Gu, Y.; Chen, H.; Wang, Y.; Li, F. Sensitive electrochemical detection of DNA damage based on in situ double strand growth via hybridization chain reaction. Anal. Bioanal. Chem. 2017, 409, 6821-6829. [CrossRef]

31. Wang, X.; Yang, T.; Jiao, K. Electrochemical sensing the DNA damage in situ induced by a cathodic process based on $\mathrm{Fe}_{\mathrm{F}} \mathrm{Fe}_{2} \mathrm{O}_{3}$ core-shell nanonecklace and Au nanoparticles mimicking metal toxicity pathways in vivo. Biosens. Bioelectron. 2009, 25, 668-673. [CrossRef]

32. Zhang, Q.; Dai, P.; Yang, Z. Sensitive DNA-hybridization biosensors based on gold nanoparticles for testing DNA damage by Cd(II) ions. Microchim. Acta 2011, 173, 347-352. [CrossRef] 
33. Uttayarat, P.; Tangtong, T.; Sukapirom, K.; Boonsirichai, K. Gamma irradiation induces DNA double-strand breaks in fibroblasts: A model study for the development of biodosimetry. J. Phys. Conf. Ser. 2015, 611, 012030. [CrossRef]

34. Lomax, M.E.; Folkes, L.K.; O'Neill, P. Biological consequences of radiation-induced DNA damage: Relevance to radiotherapy. Clin. Oncol. 2013, 25, 578-585. [CrossRef] [PubMed]

35. Nikitaki, Z.; Hellweg, C.E.; Georgakilas, A.G.; Ravanat, J.-L. Stress-induced DNA damage biomarkers: Applications and limitations. Front. Chem. 2015, 3, 35. [CrossRef]

36. Hassan, A.; Macedo, L.J.A.; de Souza, J.C.P.; Lima, F.C.D.A.; Crespilho, F.N. A combined Far-FTIR, FTIR Spectromicroscopy, and DFT Study of the Effect of DNA Binding on the [4Fe4S] Cluster Site in EndoIII. Sci. Rep. 2020, 10, 1931. [CrossRef]

37. Uosaki, K.; Quayum, M.E.; Nihonyanagi, S.; Kondo, T. Decomposition Processes of an Organic Monolayer Formed on Si(111) via a SiliconCarbon Bond Induced by Exposure to UV Irradiation or Ozone. Langmuir 2004, 20, 1207-1212. [CrossRef]

38. Sanche, L. Nanoscopic aspects of radiobiological damage: Fragmentation induced by secondary low-energy electrons. Mass Spectrom. Rev. 2002, 21, 349-369. [CrossRef]

39. Lipiec, E.; Kowalska, J.; Lekki, J.; Wiecheć, A.; Kwiatek, W. FTIR Microspectroscopy in Studies of DNA Damage Induced by Proton Microbeam in Single PC-3 Cells. Acta Phys. Pol. A 2012, 121, 506-509. [CrossRef]

40. Pijanka, J.K.; Kohler, A.; Yang, Y.; Dumas, P.; Chio-Srichan, S.; Manfait, M.; Sockalingum, G.D.; Sulé-Suso, J. Spectroscopic signatures of single, isolated cancer cell nuclei using synchrotron infrared microscopy. Analyst 2009, 134, 1176-1181. [CrossRef]

41. Ricciardi, V.; Portaccio, M.; Manti, L.; Lepore, M. An FTIR Microspectroscopy Ratiometric Approach for Monitoring X-ray Irradiation Effects on SH-SY5Y Human Neuroblastoma Cells. Appl. Sci. 2020, 10, 2974. [CrossRef]

42. Hamad, A.M.; Fahmy, H.M.; Elshemey, W.M. FT-IR spectral features of DNA as markers for the detection of liver preservation using irradiation. Radiat. Phys. Chem. 2020, 166, 108522. [CrossRef]

43. Du, G.-F.; Fu, H.-H.; Wu, R. Vibration-enhanced spin-selective transport of electrons in the DNA double helix. Phys. Rev. B 2020, 102, 035431. [CrossRef]

44. Zhang, L.; Hao, Y.; Qin, W.; Xie, S.; Qu, F. Chiral-induced spin selectivity: A polaron transport model. Phys. Rev. B 2020, 102, 214303. [CrossRef]

45. Fransson, J. Vibrational origin of exchange splitting and "chiral-induced spin selectivity. Phys. Rev. B 2020, 102, 235416. [CrossRef]

46. Fransson, J. Charge Redistribution and Spin Polarization Driven by Correlation Induced Electron Exchange in Chiral Molecules. Nano Lett. 2021, 21, 3026-3032. [CrossRef]

47. Bian, X.; Wu, Y.; Teh, H.-H.; Zhou, Z.; Chen, H.-T.; Subotnik, J.E. Modeling nonadiabatic dynamics with degenerate electronic states, intersystem crossing, and spin separation: A key goal for chemical physics. J. Chem. Phys. 2021, 154, 110901. [CrossRef] 